\title{
CARTOGRAFIA DA DANÇA. SEGREGAÇÃO E ESTILOS DE VIDA NAS MARGENS DA CIDADE ${ }^{1}$
}

Otávio Ribeiro Raposo

\section{Introdução}

Este artigo pretende contribuir para a reflexão acerca dos estilos de vida e das dinâmicas de segregação socioespaciais, sobretudo entre jovens de áreas marcadas por processos de precarização, tendo como foco um grupo de dançarinos de break dance ${ }^{2}$ das favelas da Maré, Rio de Janeiro. Eles não são apenas b-boys ou b-girls (dançarinos de break dance), mas também dinamizadores ativos da cultura hip-hop, num bairro representado como caótico e incivilizado, um "espaço ferido" por violências estruturais e discursivas (Ferrándiz 2002:9). Protagonistas das ações culturais que impulsionam, estes jovens criaram espaços próprios de convívio onde aprimoram a dança e o conhecimento sobre o "mundo b-boy". Utilizam a componente performativa como meio de ascender a uma existência valorizada, ao mesmo tempo em que constroem parâmetros mais abrangentes de inserção na vida urbana. Ao contestarem estereótipos e transporem os muros simbólicos que os querem isolados e anônimos nas margens da cidade, criam identidades positivas que subvertem o seu lugar na hierarquia social.

A partir de uma pesquisa etnográfica realizada entre julho de 2009 e dezembro de 2010, ${ }^{3}$ quis conhecer o cotidiano dos dançarinos da Maré, cuja centralidade do hip-hop adquire uma importância ímpar na construção das suas trajetórias de vida e na afirmação de um modo particular de viver a juventude. A minha presença nos treinos de break dance, momentos densos de sociabilidade e valor simbólico, permitiu a construção de uma relação de confiança e a obtenção de interlocutores privilegiados. ${ }^{4}$ Partindo do modo como os jovens mobilizavam essa prática cultural, pude observá-los não só nos seus territórios de encontro e lazer no próprio bairro, como também acompanhar os seus movimentos pelo circuito hip-hop do Rio de Janeiro. A ênfase numa microperspectiva para compreender práticas e rotinas extre- 
mamente ricas de viver o urbano teve a intenção de produzir uma visão humanizada sobre o bairro e a cidade, em que o ponto de vista do citadino foi privilegiado. Por outro lado, transformar um pequeno fragmento da cidade, apreendido em termos etnográficos, num conhecimento urbano de caráter mais universal constitui um dos desafios derradeiros da antropologia urbana (Cordeiro 2010:12), estando inserido no debate heurístico sobre as possibilidades de "fazer" uma "antropologia da cidade" (Eames \& Goode 1977; Agier 2011).

Muro da vergonha.

Segregação e juventude nas margens da cidade

Em março de 2010, muitos trabalhadores percorriam os arredores das favelas da Maré para dar início a uma importante obra da Prefeitura do Rio de Janeiro. Não iam construir uma escola, tampouco tinham o propósito de remodelar ou ampliar as débeis infraestruturas do bairro, formado por 16 favelas e habitado por quase 130 mil pessoas segundo o último censo do IBGE. ${ }^{5}$ Estavam lá para erguer um muro de 11 quilômetros a separar a Maré de duas importantes vias rápidas, a Linha Amarela e a Linha Vermelha, sob a justificativa de criar um isolamento acústico para os moradores. Mas a maior parte da população do bairro e grande parte das lideranças locais não concordavam com este argumento. ${ }^{6}$ Para Roseny, vice-presidente da Associação de Moradores da Nova Holanda, o muro tinha a intenção de "varrer para debaixo do tapete os problemas da cidade". O seu objetivo seria esconder as favelas dos turistas estrangeiros e das comitivas governamentais que visitariam o Rio de Janeiro durante os megaeventos que a cidade sediaria em breve: Copa do Mundo de Futebol (2014) e Olimpíadas (2016). Outros residentes consideravam um desperdício de dinheiro público os $\mathrm{R} \$$ 20 milhões estimados para serem gastos na sua construção, quando haveria áreas prioritárias nas quais investir, como o lazer, a educação e a saúde. Indagado sobre a possibilidade de o muro servir para diminuir a exposição das famílias ao barulho dos veículos nas vias rápidas, o dançarino Weltom respondeu:

É mentira! Eles estão construindo o muro para impedir que a favela seja vista pelas pessoas, principalmente os turistas que vêm do aeroporto [Weltom, 18 anos. Diário de Campo, 31 de março de 2010]. 
A obra foi denominada "muro da vergonha" por instituições e organizações não governamentais (ONGs) locais e, no dia 8 de maio de 2010, realizou-se um protesto para denunciá-la. ${ }^{7}$ A mobilização, contudo, não conseguiu travar o plano do governo, e a edificação do muro decorreu sem maiores incidentes. Atualmente, aqueles que chegam ao Rio de Janeiro pelo Aeroporto Internacional ou pela Linha Vermelha já não avistam as favelas da Maré na sua totalidade ${ }_{1}^{8}$ uma paisagem que incomoda as elites cariocas, tão apegadas ao imaginário de "cidade maravilhosa". O muro da Maré ilustra o urbanismo hegemônico em vigor no Rio de Janeiro, cujas prioridades são a maquiagem da cidade, a valorização fundiária e o incremento do turismo em detrimento da qualidade de vida da população. ${ }^{9}$ Estas dinâmicas, ao aprofundarem a desigualdade entre os territórios, atuam decisivamente na produção da segregação socioespacial.

No Brasil, e no Rio de Janeiro em particular, o padrão de segregação fomentou uma alteridade que fez da favela e dos seus moradores o "outro" por excelência. ${ }^{10} \mathrm{O}$ processo de urbanização na antiga capital federal, desde o início, foi marcado pela desigual apropriação de terras entre diferentes setores da população, no quadro de uma organização do espaço urbano moldada por disparidades estruturais na distribuição da riqueza, acentuada após as reformas urbanas de Francisco Pereira Passos no início do século XX. Conhecido como o prefeito "bota-abaixo", Pereira Passos abriu grandes avenidas e construiu edifícios imponentes, visando transformar a cidade numa metrópole moderna e europeizada. Apesar da falta de moradia, num período em que o Rio de Janeiro crescia vertiginosamente em função da migração rural-urbana ${ }^{11}$ numerosos cortiços foram demolidos na tentativa de elitizar o seu centro, afastando os pobres para as periferias (Valladares 2008).

Todavia, a periferização da população mais pobre não ocorreu como o planejado, dado que a geografia carioca - cercada de morros e florestas dificulta a especulação imobiliária e o controle oficial desses espaços não urbanizados. Ao contrário do pretendido, muitas famílias, para se manterem próximas de seus empregos, foram morar nos morros. Sob o argumento de tentar higienizar e impor um estilo de vida moderno e civilizado, as intervenções urbanísticas do passado acabaram por favorecer o crescimento das favelas (Zaluar \& Alvito 2006). Estas consolidaram-se no espaço urbano carioca mesmo em bairros que se pretendiam exclusivos das classes mais abastadas, em geral concentradas na sua zona sul, o que permitiu uma relativa proximidade física entre ricos e pobres. ${ }^{12}$

Discernir distintas áreas da cidade a partir de dinâmicas territorializadas que excluem uma parte da população da igualdade política poderá ser frutífero para a compreensão dos processos de precarização da vida urbana. 
Neste sentido, o termo "região moral", de Robert Park (1973:66), ajuda-nos a conhecer "áreas naturais" de segregação e a enquadrar identidades urbanas estigmatizadas, muitas vezes ligadas a territórios específicos. ${ }^{13}$ No caso da Maré isto é evidente, pois o fato de ser formada por várias favelas - concentrações habitacionais marcadas por estereótipos - configura-a como uma "região moral" no Rio de Janeiro, condicionando representações e políticas públicas diferenciadas. O papel do Estado na gestão dessas regiões morais e marginalizadas - em termos espaciais, sociais e políticos - como é o caso das favelas, não pode ser desconsiderado, como aponta o esquema analítico proposto por Das e Poole (2004). Segundo as autoras, os territórios à "margem do Estado" são fabricações estatais, na medida em que são atravessados por formas de regulação distintas no que se refere, por exemplo, à aplicação da lei e à atuação das forças da ordem (2004).

Os dispositivos urbanos, enquanto "tecnologias de poder" (Foucault 1977:116), são centrais para manter afastados do poder político e econômico aqueles que vivem nessas margens, produzindo uma "alteridade definida por dissecação e separação, por distância e por oposição a um território formado pela cidade e pelo Estado" (Agier 2015:50). Nesse processo, representações (e acusações) desumanizadoras e criminalizantes sobre os habitantes transformam as áreas marginalizadas em espaços de exceção (Das \& Poole 2004), pondo em prática regimes territoriais marcados pelo controle social e pelo afastamento, pela lógica do enclausuramento e da violência extralegal das ações policiais. Seguindo este raciocínio, o muro da Maré é um dispositivo urbano de controle-regulação-dominação que reafirma não só o estatuto subalterno e indesejado dos moradores do bairro, mas o próprio caráter repressor das políticas estatais nesses territórios.

O modelo de cidadania no Brasil foi teorizado por inúmeros pesquisadores que apontaram tanto as suas características hierárquicas (Velho \& Alvito 1996; Zaluar 1996) como a desigualdade de direitos entre cidadãos (Machado da Silva 2008; Silva \& Barbosa 2005). Diferente da maior parte dos países europeus e dos EUA, em que os valores do individualismo possibilitaram a crença (e a conquista parcial) da universalidade dos direitos, persiste no Brasil o modelo hierárquico em parte significativo das relações sociais. Tal realidade deriva tanto dos processos históricos que o país atravessou - em que a herança da escravidão é um dos seus pilares - como da sua conjuntura socioeconômica atual, marcadamente desigual e injusta. ${ }^{14}$ O termo "cidadania de geometria variável" ajuda-nos a compreender essa desigualdade de direitos (Machado da Silva \& Leite 2008:54), realçando a ideia de que a qualidade da cidadania brasileira varia conforme o nível salarial, o lugar de moradia, a cor da pele, a escolaridade, entre outros atributos. 
As favelas foram o alvo principal de políticas públicas repressivas e preconceituosas desde a década de $1920 .{ }^{15}$ Tais políticas cumpriram a dupla função de confinar e controlar os seus habitantes, considerados incivilizados e indignos, fiéis representantes de uma classe perigosa. Representadas como territórios marcados pela anomia ${ }^{16}$ na "cartografia imaginária dos citadinos" (Agier 2011:67), às favelas é atribuído um sentido de alteridade radical, que seria o avesso da condição citadina. Essa perspectiva ganhou contornos ainda mais contundentes com o crescimento da violência urbana nas últimas décadas ${ }_{1}{ }^{17}$ legitimando a criminalização de pessoas e territórios à escala da cidade. A responsabilização dos moradores das favelas pela desordem foi então potencializada, dando eficácia simbólica a um conjunto de metáforas e artificialismos duais: "cidade partida", "asfalto x favela", "cidade legal x cidade ilegal". Essas visões moralistas consolidaram a imagem dos moradores de favelas como prováveis delinquentes, ${ }^{18}$ tornando a brutalidade policial aceitável para grande parte da população brasileira. Neste caso, a linguagem dos direitos humanos perde a eficácia perante uma demanda das classes mais abastadas por um tipo de segurança pública que privilegia os bairros ricos e a propriedade privada. É assim que se torna flagrante a parcialidade dos direitos daqueles que vivem nas margens da cidade, pela diferença no tratamento que recebem da polícia, da mídia ou no acesso à Justiça.

A convivência obrigatória e inescapável da população das favelas com os bandos armados (em função da proximidade espacial) é interpretada como cumplicidade por extensos setores da sociedade. A reputação de criminoso que paira sobre os habitantes das favelas foi denunciada pelo dançarino Rick:

A gente está constantemente vivendo com a violência e tentando viver em meio a isso, tentando continuar com as nossas vidas, e quem está do lado de fora não vê isso. Só veem pessoas que convivem com o crime e que podem qualquer dia virar criminosos também [Rick, 19 anos. Entrevista, 18 de setembro de 2010].

Rotulados como bandidos em potencial por parte da opinião pública, é comum instituições do Estado não os reconhecerem e as suas organizações como legítimos interlocutores nas arenas políticas. Esta criminalização prévia retira-lhes o "poder da palavra" e condena-os ao isolamento, num processo de segregação socioespacial reforçado tanto pela precariedade econômica como pela discriminação "racial" (quando se trata de negros), numa "superposição de vulnerabilidades" que restringe o acesso dos moradores das favelas à cidade (Fridman 2008:81).

Os jovens são os mais atingidos, tanto pelos discursos que estigmatizam as populações das favelas como pela repressão policial e a arbitrariedade do tráfico de drogas. As dificuldades e os perigos enfrentados para circular em 
localidades dominadas por facções rivais próximas à sua área de residência são muito maiores devido ao fato de serem facilmente considerados membros de grupos criminosos locais ou adversários. ${ }^{19}$

Historicamente transformados num problema social, os jovens das classes desfavorecidas costumam ser alvo de um discurso que tende a homogeneizá-los em torno de duas perspectivas principais. A primeira essencializa-os na imagética da pobreza, da carência e da violência. Obrigados a uma luta constante pela sobrevivência que lhes retiraria imaginação e capacidade criativa, eles viveriam num vazio de ideias e cultura, apenas superado pela boa vontade de ONGs e "almas caridosas", responsáveis por levar-lhes civilização e retirar alguns deles (poucos) da barbárie em que estariam mergulhados. É neste contexto que os "jovens-problema" são convertidos em "jovens-solução" (De Tommasi 2013, 2014), quando dispositivos de gestão (pública ou privada) passam a intervir prioritariamente em populações jovens e "de baixa renda", cumprindo alguns dos integrantes do público-alvo a função de mediadores em projetos de "responsabilidade social". No caso dos jovens das favelas cariocas, seria o perigo iminente de eles ingressarem em quadrilhas criminosas o que tornaria urgente a atuação de "projetos sociais" em seu território. Ao considerar esses jovens inerentemente "problemáticos" e "carentes", tais projetos, em grande medida, reproduzem estereótipos e uma visão moralista na tentativa de "salvá-los e reintegrá-los à ordem social" (Abramo 1997:26).

A segunda perspectiva dá ênfase aos comportamentos rebeldes e contestatórios desses jovens, numa análise que tende a sobrevalorizar o caráter de resistência das suas práticas culturais. Influenciadas pelo aparecimento de culturas juvenis "espetaculares" (teddy boys, rockers, mods e punks), essas "contraculturas" eram pensadas a partir da premissa de que atuariam como uma espécie de "resposta subcultural" aos problemas decorrentes das relações antagônicas de classe e da crise da cultura parental. ${ }^{20}$ Limitadas a reagir, as ações desses grupos juvenis não seriam dotadas de agência, pois estariam condicionadas a responder a um "outro" hierarquicamente superior, encarcerando a sua existência à mera posição de coadjuvante.

Mais do que nunca, torna-se fundamental pluralizar juventudes para pôr em evidência diferentes maneiras de viver a condição juvenil e trazer à discussão a heterogeneidade de estilos de vida, valores e padrões culturais, além de trajetos e projetos distintos e não lineares. Se a idade é um eixo estruturante na organização social de qualquer sociedade, o critério etário na compreensão do conceito de juventude apresenta um fraco cariz explicativo. É esta a opinião de Bourdieu (2008), para quem “a juventude é apenas uma palavra". Para contrariar uma visão essencialista do termo, importa analisar a juventude como "uma posição" a partir da qual se concebe e se vive num mundo em permanente mudança (Canclini et al. 2012:9). 
As expressões artística e cultural, antes vedadas às camadas populares, consideradas um grande amálgama de indivíduos "não instruídos e não cultivados", deixou de ser exclusiva das elites (Lopes 2000:18). Isto é claro nas margens da cidade - geralmente favelas e periferias urbanas cuja efervescência cultural é responsável por gerar parte substancial das novidades musicais, estéticas, linguísticas e de dança. Muitos dos jovens dessas áreas deixaram de ser meros consumidores para transformarem-se em ativos produtores culturais, apropriando-se das manifestações artísticas não apenas por divertimento, mas também para "redefinir as suas identidades coletivas, reclamar direitos e afirmar um modo específico de viver a juventude" (Aderaldo e Raposo 2016:282). Não por acaso, são estes mesmos jovens que estão a desenvolver as estratégias mais criativas para driblar os dispositivos de confinamento territorial e simbólico, utilizando as práticas artístico-culturais como instrumentos de usufruto do espaço público e de acesso aos direitos de cidadania. São estas dimensões que procurarei ilustrar nas páginas seguintes, ao debater o modo como os dançarinos de break dance da Maré intensificam a sua experiência urbana, fazendo deste estilo juvenil um espaço de convergência tanto entre moradores de várias favelas do bairro (controladas por quadrilhas rivais) como também entre jovens de diferentes percursos e classes sociais do Rio de Janeiro.

\section{Fronteiras e violência na Maré. A união dos dançarinos do bairro}

Diferentes facções do tráfico de drogas, às quais se soma a presença de uma milícia ${ }^{21}$ costumam disputar o domínio da Maré. As áreas que estabelecem fronteiras entre essas organizações criminosas são temidas e evitadas pelos moradores, pois os confrontos armados são frequentes e produzem, não raramente, mortos e feridos. Para marcar simbolicamente o controle territorial, inúmeros grafites com as abreviaturas dos respectivos grupos estão inscritos nas paredes do bairro - CV (Comando Vermelho), TCP (Terceiro Comando Puro) e ADA (Amigos dos Amigos) - em geral acompanhados dos apelidos de traficantes locais. A palavra "saudade" sobressai nos grafites, uma forma de homenagear os mortos nos embates com a polícia ou quadrilhas rivais.

Na figura 1 vemos o bairro da Maré com a indicação das suas favelas e equipamentos mais importantes. Ao lado, na figura 2, está a disposição dos grupos armados nas favelas do bairro em julho de $2009 .^{22}$ 
Figura 1: Mapa geral da Maré. Fonte: CEASM

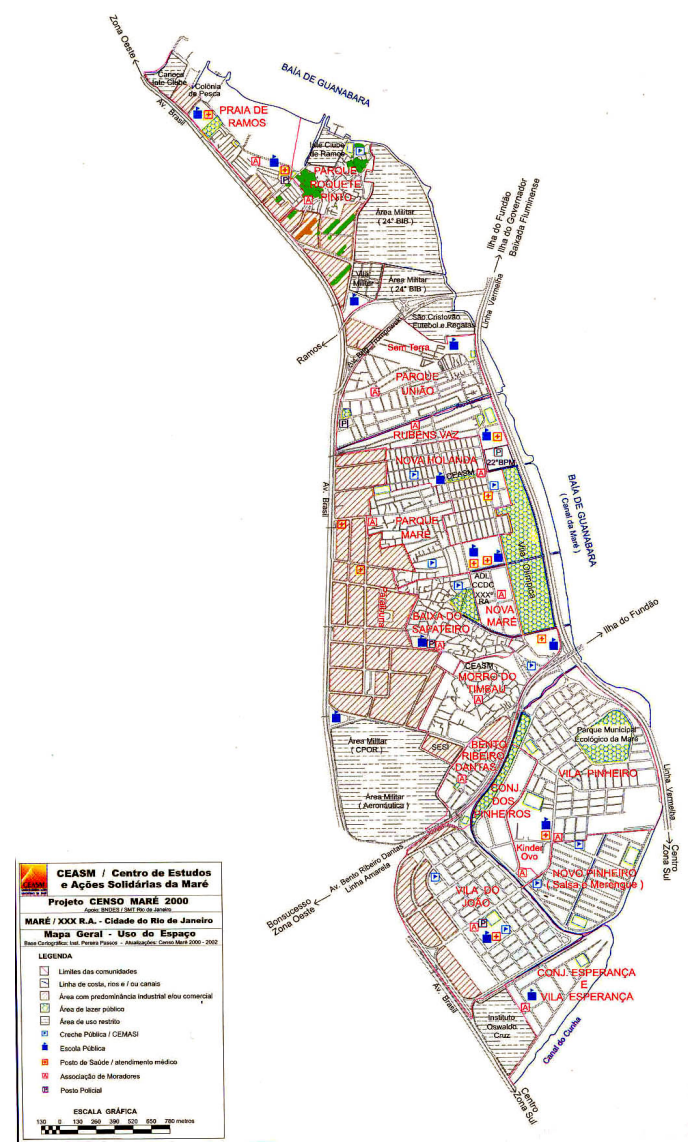

Figura 2: Disposição dos grupos armados na Maré em julho de 2009

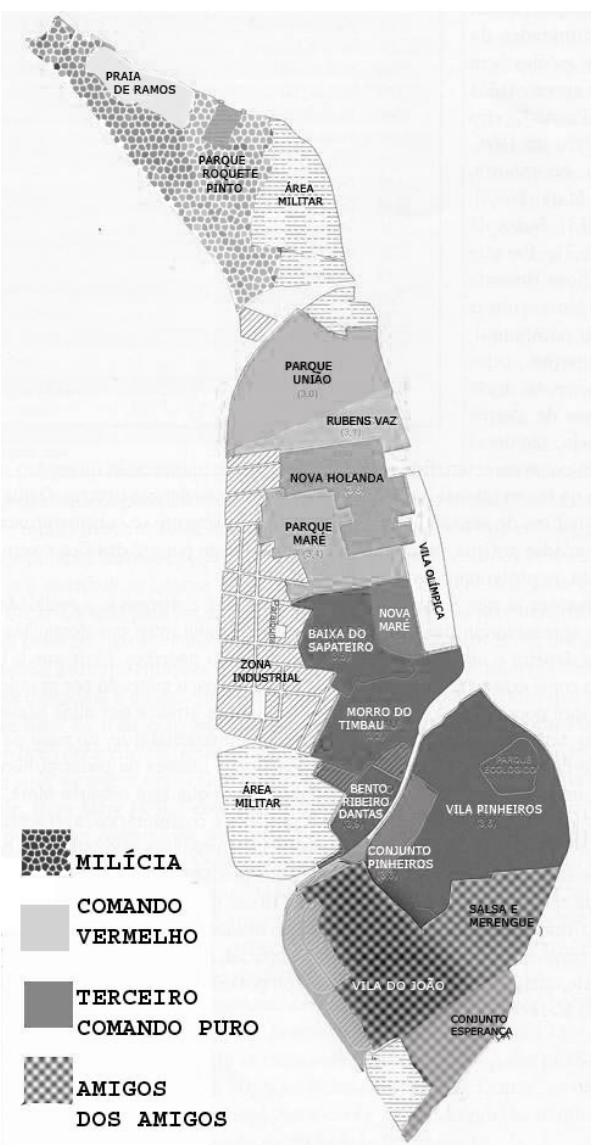

No topo do mapa, em forma de vitrais, estão as áreas dominadas pelas milícias: Conjunto Marcílio Dias, ${ }^{23}$ praia de Ramos e Parque Roquete Pinto. As favelas controladas pela facção CV estão em cinzento claro: Parque União, Parque Rubens Vaz, Nova Holanda e Parque Maré. O domínio territorial do TCP está em cinzento escuro e abrange a Baixa do Sapateiro, Nova Maré, morro do Timbau, Conjunto Bento Ribeiro Dantas, Vila do Pinheiro e Conjunto Pinheiros. A facção ADA, por sua vez, está identificada nas localidades marcadas em xadrez, e a sua implantação na Maré abarcava as favelas Salsa e Merengue, Vila do João e Conjunto Esperança.

A circulação dos habitantes nas localidades da Maré controladas por quadrilhas rivais à da sua área de residência é desincentivada por esses grupos, que receiam a transmissão de informações privilegiadas aos adver- 
sários. Embora não haja regras explícitas na Maré proibindo as pessoas de transitar por "favelas rivais", os relatos de arbitrariedades cumprem um papel decisivo. O medo estimula a autocensura dos moradores. Assim, o temor de serem acusados de espiões de uma facção inimiga - a categoria emic nas favelas é "X-9" - faz com que a maior parte evite atravessar as fronteiras, circulando apenas nas localidades controladas pela mesma quadrilha da sua área de residência.

Se o recurso à força e à intimidação constitui parte fundamental da lógica de dominação dessas organizações criminosas, não menos importante é a pressão simbólica que elas exercem sobre os moradores, principalmente os jovens. Desde muito nova, a juventude da Maré é coagida a permanecer dentro dos limites impostos pelos traficantes locais. Apelidado de "alemão", o jovem que habita uma favela rival é considerado inimigo, malfeitor, pessoa não confiável ou merecedora de respeito. Nas escolas e nos equipamentos culturais do bairro ${ }^{24}$ não é raro haver brigas entre adolescentes que vivem em lados opostos da fronteira, sendo comuns os comentários que exaltam as ações violentas desses grupos. Estudantes de uma escola pública da Nova Holanda, por exemplo, pressionaram os professores a não utilizar o algarismo 3, associado simbolicamente ao Terceiro Comando Puro, sugerindo a utilização da expressão $2+1$. Portanto, não será exagero afirmar que as quadrilhas do tráfico de drogas proporcionam a muitos jovens da Maré, inclusive àqueles que não estão envolvidos no crime, referenciais importantes na construção dos vínculos identitários, expressos em insígnias, gírias e códigos de honra que, em parte, adotam. Esta vinculação simbólica à facção da sua área de residência contribui para restringir a mobilidade e as redes de amizade desses jovens, o que é agravado pelos constantes confrontos armados entre traficantes e pela ação violenta da polícia.

Contrariando esta dinâmica, a adesão ao break dance permitiu que os jovens contornassem as barreiras reais e simbólicas impostas pelas quadrilhas que disputam o monopólio do tráfico de drogas na Maré, um recurso que minimizou as restrições à sua circulação no bairro. Carregado de medo e tensão, foi um processo paulatino, como é possível depreender do depoimento abaixo.

Antigamente, a gente tinha muito medo desse lance de facção. A gente ficava aqui de um lado, eles no outro lado. Então a gente não passava para outras comunidades que eram de uma facção rival de jeito nenhum, porque a gente sempre tinha na cabeça aquela parada: "se a gente passar para lá, eles vão pegar a gente, vão bater, podem até matar. Quando a gente começou a dançar, o Rick a grafitar (o Rômulo também), o que aconteceu? A gente começou, meio 
com medo, a ir para o outro lado, eles virem para cá, mas foi de pouquinho em pouquinho. Quando a gente foi ver, a gente estava indo para lá direto, de lá indo para outra comunidade, voltando, indo para campeonato em comunidade de facção rival [Duda, 20 anos. Entrevista, 5 de novembro de 2009].

Até ingressarem no break dance, as redes de amizades dos dançarinos da Maré estavam concentradas nas localidades onde viviam. Eles não circulavam para outras favelas do bairro, a não ser aquelas controladas pela quadrilha da sua área de residência, devido ao temor que tinham de sofrer punições infundadas. Não por acaso, o break dance desenvolveu-se na Maré a partir de três núcleos distintos localizados em áreas subjugadas pelas três facções da altura. Os núcleos iniciais foram:

- $\quad$ os jovens da Nova Holanda, favela sob a influência do CV, começaram a dançar nas oficinas promovidas pelo Centro de Estudos e Ações Solidárias da Maré (CEASM), naquela localidade.

- $\quad$ os jovens do morro do Timbau que antes de dançar break dance tinham aulas de street dance ${ }^{25}$ no Museu da Maré, junto ao morro do Timbau, um território dominado pelo TCP.

- $\quad$ os jovens da Vila do Pinheiro e da Vila do João, que receberam as primeiras noções de dança na Ação Comunitária do Brasil, uma ONG da Vila do João, favela que até setembro de 2009 fazia parte do domínio da ADA.

Foi no âmbito de uma parceria entre o CEASM e as escolas públicas da região que o break dance veio para a Maré em 2001, quando uma das diretoras dessa ONG convidou Luck e Reis para dinamizarem um projeto de hip-hop. Embora morassem na Rocinha, conseguiram formar um grupo de empenhados dançarinos, principalmente na Nova Holanda, onde animavam oficinas de hip-hop para os moradores. À medida que crescia o número de jovens interessados no break dance, novos grupos de dançarinos emergiram, nomeadamente no morro do Timbau, Vila do Pinheiro e Vila do João. Mediadores por excelência do circuito break dance da cidade, estes professores juntaram todos os dançarinos do bairro, pela primeira vez, num evento no morro do Timbau em 2007. Este encontro inaugurou uma nova etapa na prática do break dance na Maré, quando jovens de lados opostos da "barricada" conheceram-se e passaram a treinar juntos, vencendo o medo imposto pelas quadrilhas do tráfico. Luck e Reis foram determinantes nesse processo, incentivando os dançarinos da Maré a ganharem coragem para frequentar localidades até então interditas. Pioneiros em levar o break dance à Maré, eles davam aulas em várias partes do bairro e mediaram novos encontros entre os dançarinos. Se, inicialmente, levavam e traziam 
os jovens para as atividades que promoviam nas localidades "proibidas", posteriormente, passaram a marcar pontos de encontro, acompanhando-os apenas parte do caminho. Aos poucos, os jovens começaram a percorrer os itinerários autonomamente.

Como resultado da reformulação das redes de amizade dos dançarinos e da convivência conjunta na Maré, os núcleos principais de break dance aproximaram-se e fundiram-se num só. Passaram a integrar o mesmo coletivo pessoas que viviam em favelas dominadas por diferentes quadrilhas criminosas, como, por exemplo, Nova Holanda, Parque União, Parque Rubens Vaz, morro do Timbau, Vila do Pinheiro e praia de Ramos.

A partilha de experiências na dança e a formulação de um conjunto de reflexões sobre a cultura hip-hop foram a base de uma intensa relação afetiva que tornou alguns desses jovens amigos inseparáveis. Para celebrar essa unificação, formaram uma nova $\mathrm{crew}^{26}$ na Maré, a Ativa Breakers. Esta servia para identificá-los nas disputas de campeonatos ou quando participavam de eventos, sendo o resultado organizativo da afirmação da amizade no interior do grupo.

\section{Saltando as barreiras do tráfico}

Uma antiga fábrica abandonada na favela Parque União - a Tecno tornou-se o principal ponto de encontro para a prática de break dance na Maré. Este espaço oferecia maior liberdade aos jovens, ao não submetê-los a horários rígidos e à disciplina imposta pelas oficinas do CEASM, além de possibilitar-lhes mais treinos ao longo da semana. Mais que um mero local de ensaio, vivia-se densas sociabilidades na Tecno: era ali que os jovens confraternizavam entre si, trocavam informações sobre o estilo e "jogavam conversa fora", construindo um modo particular de viver a juventude. A dinâmica dos ensaios na Tecno não sofria a interferência de professores ou técnicos de projetos sociais, sendo os próprios jovens que definiam o formato dos treinos (movimentos a ensaiar, músicas a ouvir, orientação dos iniciantes) e que garantiam aspectos logísticos, como limpeza, iluminação, sistema de som etc. Eram "sociabilidades desafogadas" (Pais 1994:114), na medida em que os ensaios eram destituídos de vigilância ou controle institucional por parte de pessoas exteriores ao grupo. Neste cenário de autonomia, a dança, as conversas em tom jocoso, os risos e os aplausos os conectavam numa teia de cumplicidade criadora de um sentido de "nós", reunindo os jovens sob um mesmo território, estilo e imaginário. 
Os espaços utilizados para a prática do break dance na Maré eram sete:

- Tecno: principal local de treino dos dançarinos da Maré.

- Oficina da Redes: ensaios promovidos pela ONG Redes nas suas instalações.

- Ciclovia: área de lazer onde os jovens treinavam movimentos acrobáticos.

- Piscinão de Ramos: equipamento de lazer dos moradores da Maré e de bairros adjacentes.

- Casa de Fábio: local de ensaio improvisado na laje da casa de um dos b-boys.

- Praça da Nova Holanda: ensaiou-se semanalmente nesta praça com o intuito de divulgar o break dance no bairro.

- Associação na Vila do Pinheiro: local de treino de outro grupo de b-boys da Maré, frequentado pontualmente pelos dançarinos da Tecno. ${ }^{27}$

Adeptos de um estilo pouco usual no bairro, estes jovens conquistaram reconhecimento no interior da Maré, inclusive dos traficantes. Passaram a ser identificados como o "pessoal do hip-hop", dispondo de uma relativa tranquilidade para transitar entre as diferentes favelas.

Até a bandidagem sabe o porquê da gente estar circulando no lado de lá. E até eles respeitam esse lance da gente estar fazendo breaking, eles sabem. Eles mesmos falam: "Ah! Eles são do hip-hop". Para a gente é bom, porque a gente está vendo que eles estão respeitando. E o breaking ajudou a quebrar esse tabu, essa barreira... [Rick, 19 anos. Entrevista, 5 de novembro de 2009].

Ao atravessarem as barreiras que os prendiam à sua vizinhança, os jovens alteraram o modo de se relacionar com o bairro, atenuando os constrangimentos do seu dia a dia, marcado por impedimentos no direito de ir e vir. Os bloqueios impostos pelo tráfico e pela polícia não são imóveis, podendo "ser relativizados por pertencimentos diversos" (Leite \& Machado da Silva 2013:155). As camisas coloridas, os bonés de abas planas e os tênis de marca são alguns dos marcadores culturais que evocam o estatuto de b-boy. Este, por sua vez, confere-lhes legitimidade para circular pela Maré, proporcionando-lhes um afastamento simbólico do campo da criminalidade. Por isso, o break dance atua como uma esfera de sentido capaz de restaurar a segurança ontológica dos seus praticantes, já que diminui consideravelmente os riscos de serem alvos do despotismo dos traficantes. A estratégia de transpor as fronteiras não é uma exclusividade desses dançarinos, pois outros grupos sociais - mães, evangélicos, skatistas, trabalhadores de ONGs - acionam diferentes pertenças para poderem circular pelo bairro. 
Os mapas apresentados abaixo são reveladores da limitada experiência urbana da maioria dos jovens com o próprio bairro, na medida em que a experiência radical de fronteira, derivada das rivalidades entre traficantes, conforma uma alteridade impeditiva da plena circulação pela Maré. Contudo, o desconhecimento das localidades "outras" transformou-se a partir da adesão ao break dance, quando o perímetro de circulação e o acesso a locais de lazer se expandiram consideravelmente. Embora os mapas apresentados reproduzam os percursos de apenas dois dançarinos, estes são muito semelhantes aos do conjunto de b-boys e b-girls do bairro. ${ }^{28}$

Figura 3: Mapa do percurso do b-boy Rômulo na Maré. Fonte: Google Maps

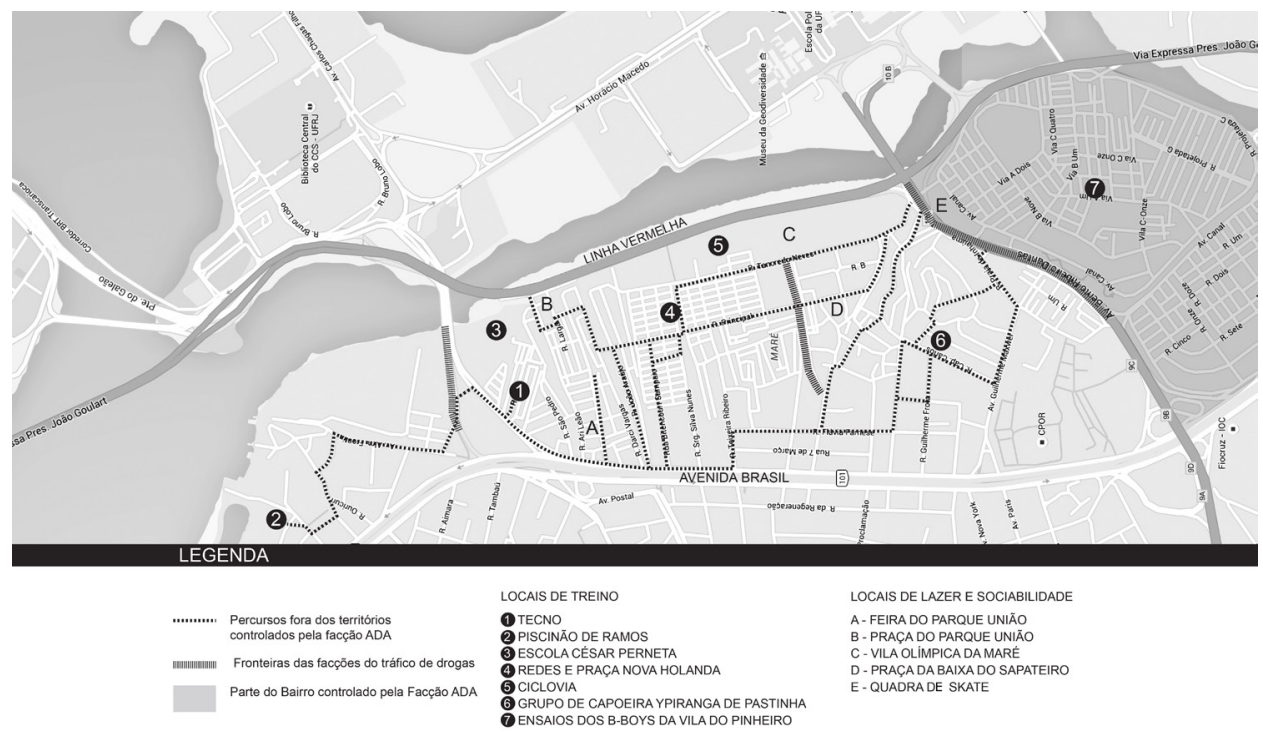

Na figura 3, a mancha cinzenta refere-se à zona do bairro a que estava restrita a circulação do b-boy Rômulo antes de ingressar no break dance, e que correspondia exatamente ao perímetro dominado pela facção do tráfico de drogas ADA que controlava a sua vizinhança: ${ }^{29}$ Vila do Pinheiro, Conjunto Pinheiros, Salsa e Merengue, Vila do João e Conjunto Esperança. As fronteiras do tráfico de drogas estão em forma de trilhos e assinalam os limites territoriais de cada um dos grupos criminosos da Maré. ${ }^{30}$ Os traços descontínuos indicam os percursos do jovem fora dos limites controlados pela facção dominante na sua área de residência para encontrar amigos, ir a espaços de lazer e dançar. Como é possível ver no mapa, o b-boy Rômulo atravessava áreas dominadas por vários grupos criminosos quando ia treinar break dance na Tecno ou no Piscinão de Ramos, desenvolvendo uma visão 
de conjunto sobre o bairro e ampliando as suas redes de sociabilidade. De fato, parte significativa dos seus locais de lazer passaram a estar fora da área controlada pela quadrilha que atua na sua vizinhança, como fica patente no mapa.

Figura 4: Mapa do percurso do b-boy Weltom na Maré. Fonte: Google Maps

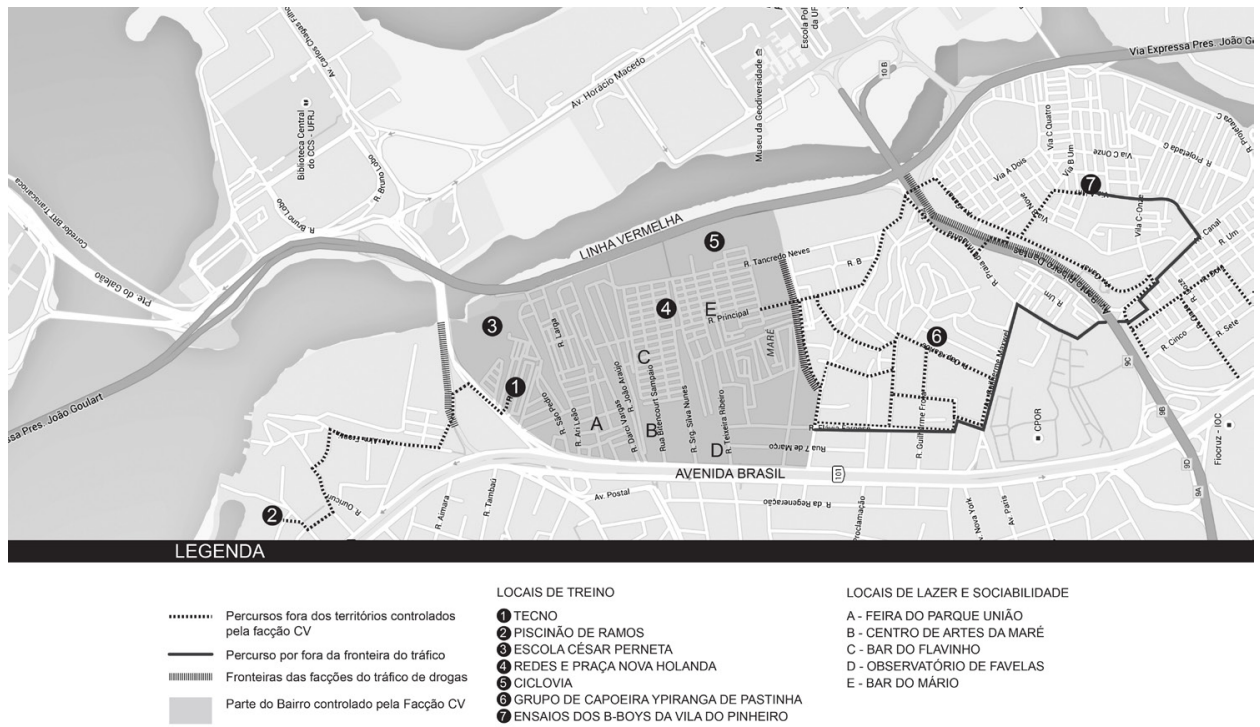

A figura 4 indica os percursos do Weltom, morador na área das favelas controladas pelo CV: Nova Holanda, Parque Maré, Parque Rubens Vaz e Parque União. Estas localidades estão assinaladas em cinzento e coincidem exatamente com a área a que estavam circunscritos os seus trajetos na Maré antes de ingressar no break dance. Ao contrário de Rômulo, a maior parte dos locais de sociabilidade que Weltom passou a frequentar após o ingresso no estilo localizava-se nas favelas controladas pela facção da sua área de residência, o que se explica pelo fato de o circuito breaking do bairro estar concentrado nesse perímetro, tal como grande parte da oferta de equipamentos culturais e de lazer. Mas esta característica não impede que o jovem frequente favelas consideradas "inimigas", não só para dançar com outros b-boys, mas também para encontrar amigos, familiares e até namoradas, algo impensável anteriormente.

Se é verdade que o estatuto b-boy permite a estes jovens transpor os bloqueios impostos pelas quadrilhas criminosas, o medo e a "neurose" "31 $^{\text {ainda }}$ são realidades presentes, principalmente nas épocas em que se intensificam os confrontos armados. Dificilmente atravessam as fronteiras durante a 
noite, período em que os tiroteios são mais frequentes e os traficantes mais desconfiados. Neste caso, os jovens preferem um caminho mais longo, pela avenida Brasil ou por ruas paralelas, onde o controle do tráfico de drogas é menos intenso: ver na figura 4 o traço contínuo que aponta o desvio das fronteiras do tráfico. Fiz este percurso com Fábio para irmos aos ensaios dos b-boys da Vila do Pinheiro. Este dançarino costumava deslocar-se até lá pelas bordas da Maré, evitando as zonas de maior conflito. Mesmo assim, nunca realizava tais itinerários despreocupadamente.

Eu, se saio daqui para ir a outro lado, fico com medo, porque eu não sei se os caras podem me parar: "Você mora onde?", "Moro no Parque União". "Então você é bandido de lá?". Os caras podem te fazer uma covardia e te matar, dar um tiro, te meter a porrada. Como fazem de lá para cá também, então é chato isso porque você não pode andar à vontade. Ao entrar numa rua, você tem que saber onde está entrando: "Aqui ainda faz parte de tal comando? É o comando da minha área? E se não for?". Se o cara te estranhar e te parar? Aí ferrou, mano [Fábio, 29 anos. Entrevista, 11 de janeiro de 2010].

A partir de 2011, o principal local de dança entre os b-boys e as b-girls da Maré transferiu-se para a Escola Estadual Professor César Perneta, localizada na favela Parque União. Os jovens aproveitaram a relação privilegiada com a instituição de ensino, onde alguns estudavam, para ter acesso às suas instalações e manter os ensaios. Nos anos seguintes, eles continuaram a dançar, apesar de algumas desistências. Os dançarinos da Maré permanecem como uma referência de relevo no circuito hip-hop da cidade, embora alguns deles já não sejam propriamente tão jovens assim.

\section{A conquista do direito à cidade}

A cultura hip-hop, potenciadora de ações e encontros, fomenta o fluxo dos jovens para além das fronteiras da Maré. Nas entrevistas realizadas, eles referem que, antes de aderirem à dança, saíam pouco do bairro e tinham uma visão limitada da cidade, seja do subúrbio, seja das áreas nobres. Fazem questão de dizer que o break dance foi responsável por terem conhecido muitos locais diferentes, inclusive fora do estado do Rio de Janeiro, colocando-os em contato com jovens de outros bairros, muitos dos quais de origens e classes sociais diferentes. Tornou-se comum treinarem na Praça XV e na Lapa (centro), na Tijuca (zona norte) e em São Gonçalo (subúrbio do Rio de Janeiro); participarem em eventos e campeonatos em bairros nobres da zona sul ou em outras favelas, como a Rocinha e o Vidigal. Como relata Duda, um b-boy de 20 anos morador da Nova Holanda: 
O break dance foi o meu passaporte para ir a outros lugares, porque até então só a Nova Holanda era o meu mundo. Depois que eu conheci o breaking, eu vi que não era isso. Foi quando eu comecei, dentro da comunidade mesmo, ir para o lado do Timbau, do Pinheiro e assim foi... Fui conhecendo outras comunidades aqui dentro mesmo, porque aqui é um complexo, então existem várias comunidades, e fui passando a obter esse conhecimento. E não só aqui dentro, fora também, passei a conhecer Copacabana, Rocinha, Complexo do Alemão, Vila Kennedy, entre outras comunidades da zona sul e da zona norte. Então, com o breaking, eu percorri o Rio de Janeiro de uma ponta a outra, e até mesmo fora do Rio de Janeiro [Duda, 20 anos. Entrevista, 15 de dezembro de 2010].

Para os b-boys da Maré, os campeonatos de break dance são indissociáveis dos treinos. A rotina de ensaios fatigantes só adquire pleno sentido quando enquadrada no conjunto de eventos em que participam regularmente. Ter bons desempenhos nas competições e desfrutar de reconhecimento no circuito breaking carioca constituem recompensas inestimáveis. Eles fazem questão de enfatizar que não treinam exclusivamente para participar em campeonatos, mas "por amor à dança". No entanto, é ao abrigo desses eventos que podem ser postos à prova enquanto "b-boys de verdade". Dançar isoladamente no bairro sem enfrentar a dura concorrência de outros dançarinos não é suficientemente motivador para eles. As competições cumprem a função de pô-los em contato com a imensa rede de praticantes de break dance da cidade (e do Brasil), como também constituem a principal ferramenta para aquisição de status e prestígio. Participar em campeonatos é uma experiência épica que guardam na memória com muito carinho e satisfação, dado serem festas de consagração da cultura hip-hop em que os adeptos entram em ligação com as "energias vitais" celebradoras dessa pertença (Durkheim 1968:603). Por isso, apresentações irrepreensíveis em eventos e vitórias nas competições são motivos de glória, momentos inesquecíveis que lhes dão a sensação de serem queridos e admirados no âmbito de uma cultura prestigiada internacionalmente. Os troféus ganhos nas competições são guardados como relíquias, objetos sagrados que simbolizam suas conquistas.

Esse troféu é o que mais gosto, porque foi o primeiro que eu ganhei. Tinha acabado de fazer um ano de dança, e foi no campeonato do Reis, chamado "Batendo de Frente". Foi ali que eu percebi que tinha potencial para a dança. [...] Esse aqui foi o troféu que obtive em Petrópolis, "Duelo Imperial". Foi legal porque na modalidade "seven to smoke" o Rick ganhou, e na modalidade de dupla eu e o Túlio ficamos em $1^{\circ}$ lugar. Quando a gente chegou lá, todo mundo estava criticando a gente, e quando a gente ganhou, continuavam todos a falar 
da gente. E foi meio que uma conquista, porque ninguém nos conhecia lá. [...] Esse prêmio "Fazendo a diferença para cultura hip-hop" do Rio de Janeiro a Maré ganhou. Simbolizou a gente por estarmos seguindo mesmo a cultura (até em lance de "fundamentos") e estarmos levando a ideologia para frente, vivendo a parada [Duda, 20 anos. Entrevista, 15 de dezembro de 2010].

Os dançarinos da Maré são participantes ativos do circuito breaking carioca, cujos eventos e campeonatos alargam-se para outras cidades do estado. Sempre que podem fazem questão de ir também às competições noutros estados, principalmente em Minas Gerais e São Paulo, onde o estilo de dança é mais forte. Acompanhei os dançarinos tanto em campeonatos e encontros no Rio de Janeiro - Bradan (Madureira), Hutúz (Lapa), Original Breaking Jan (Tijuca), Session XV (Centro), GBCR (Rocinha), Inércia Inversa (Maracanã) - como noutras cidades: AKO Dance (Niterói), Master Crew (São Paulo). No entanto, o leque de eventos em que estes jovens participam é bem mais amplo, abrangendo diversos bairros do Rio de Janeiro: Estácio, Bonsucesso, Zona Portuária, Vila Isabel, Engenho de Dentro, Vigário Geral, Vidigal, Botafogo, Copacabana. E se alargam para outras cidades: Caxias, Nova Iguaçu, Belford Roxo, São Gonçalo, Petrópolis (no estado do Rio de Janeiro), Belo Horizonte e Juiz de Fora (no estado de Minas Gerais) e Porto Alegre (no estado do Rio Grande do Sul). ${ }^{32}$

O maior envolvimento com o estilo levou os jovens da Maré a lugares nunca antes frequentados. Antes de aderirem ao breaking, a maioria desenvolvia sociabilidades centradas no cotidiano local, consequência da sua reduzida circulação na cidade. A participação em eventos de hip-hop e o anseio por aceder às múltiplas referências do "mundo b-boy" multiplicaram as suas redes de amizade, ao mesmo tempo em que fomentaram o acesso ao conjunto de estilos de vida e repertórios culturais que coexistem nas chamadas sociedades complexas. Essas transformações foram extremamente importantes nas suas vidas e merecem ser aqui aprofundadas. Até porque o cotidiano de amplos setores da juventude da Maré (e de outras favelas cariocas) é dominado pela particularização espacial, um fenômeno que precariza o pleno usufruto do direito à cidade, como assinalaram os geógrafos Jailson Silva e Jorge Barbosa:

[...] a vivência em um território restrito, sem parâmetros mais abrangentes de inserção na cidade, contribui para que o lugar seja o único ponto de partida e de chegada da existência. Os moradores dos "lugares" não se sentem, muitas vezes, pertencentes à polis, onde, na perspetiva grega, o cidadão exerce o seu direito à cidade (2005:61). 
Obviamente, a particularização deve ser compreendida no contexto das dificuldades financeiras desses jovens, já que o simples ato de pegar o ônibus é problemático quando falta o dinheiro da passagem, para não falar dos custos inerentes ao lazer: cinema, show, discoteca etc. Porém, esse problema é bem mais complexo. Por se tratar de habitantes de um bairro mal-afamado, apontado pelas instituições do estado como um enclave urbano, os dispositivos de controle e confinamento espacial atuam no sentido de enclausurá-los, desincentivando a sua circulação pela urbe. Afinal, sair dos limites da favela poderá significar se deparar com uma abordagem violenta da polícia num dos checkpoints (Jeganathan 2004) montados para o evento. Não quero dizer com isto que esses jovens estejam fechados na sua área de residência. Mais importante é o fato de seu fluxo pela cidade ser invisibilizado pela posição subalterna que ocupam. Nas áreas ricas, a sua presença é aceita enquanto porteiro de edifício, empregada doméstica, balconista, pedreiro ou motorista. Posições que dificultam a interlocução em pé de igualdade com pessoas de classes sociais mais elevadas, o que é agravado pelas lógicas de segregação, racismo e privatização do lazer e do espaço público. Neste sentido, a experiência de alteridade é restrita a uma posição de subalternidade, produzindo um estreitamento das suas visões de mundo.

É a capacidade dos jovens da Maré de rearticular as profundas desigualdades sociais que marcam os territórios por onde circulam que torna importante a análise da sua participação no circuito break dance carioca. Vencerem campeonatos e destacarem-se enquanto bons dançarinos permitem aos jovens não apenas serem reconhecidos entre os adeptos desta cultura urbana, mas também inscreverem a sua presença na cidade sem estarem reféns dos rótulos que os querem inferiorizar. Assim, as "lutas simbólicas" que ocorrem nas batalhas de breaking servem para eles redefinirem o seu "mapa de prestígio" na hierarquia da cidade (Velho 2002:10). De fato, ser da Maré está associado a ser bom dançarino na cultura hip-hop do Rio de Janeiro.

[...] quando se diz que é da Maré na cultura hip-hop, a galera já conhece como bom, é sinônimo de ser bom no Rio de Janeiro. Os caras automaticamente pensam: "O moleque é bom". Porque já sabe que é daqui e tem a influência da gente [Rick, 19 anos. Entrevista, 5 de novembro de 2009].

Os jovens da Maré apropriam-se criativamente do break dance para forjar modos alternativos de circulação, imaginação e intervenção no espaço segregado da metrópole carioca. Ao promoverem uma visibilidade pública que desafia as representações hegemônicas sobre a cidade e as suas margens, fazem desta expressão artística um instrumento de "direito à cidade" (Lefebvre 2012). 
Numa sociedade pautada em estereótipos que fazem dos moradores das favelas pessoas indesejáveis, o medo de ser rejeitado ou humilhado exerce um efeito paralisante nos seus itinerários urbanos, e muitos optam por refugiar-se nos locais que lhes são familiares. Tal perspectiva também foi encontrada por Márcia Leite e Machado da Silva, cujos entrevistados revelaram uma "cartografia dos estigmas e preconceitos" (2013:153). Esta traduziria os locais que eles evitavam nas locomoções cotidianas, dados o desconforto e a insegurança de frequentar áreas da cidade onde não eram, supostamente, bem vindos pelo fato de serem pobres, negros e moradores de favelas.

A noção de "conhecimento", entendida como o $5^{\circ}$ elemento do hip-hop, ${ }^{33}$ incentiva um conjunto de saberes e questionamentos que ajuda os jovens a refletir sobre si próprios e o mundo em que estão inseridos. Nesse processo, eles buscam novas referências, num alargamento de horizontes que traz à baila uma visão política sobre o seu lugar na sociedade. A pedagogia informal encorajada pelo hip-hop fomenta um desassossego mobilizador de projetos de futuro (individuais e coletivos) contrários ao imediatismo em que muitas trajetórias juvenis se encontram encerradas. Eficaz mecanismo de controle ideológico, a presentificação da existência, estimulada por uma realidade tensionada pela violência, a escassez de recursos e os desejos de consumo, caracteriza-se pela busca irreflexiva e assídua daquilo que parece oferecer retorno imediato. O tempo presentificado estreita as possibilidades de formulação de sonhos e utopias, pois é dominado por um cotidiano regulado pelo "eterno agora", que faz do consumo um fim em si mesmo (Silva \& Barbosa 2005:61).

O jovem, indiferente ao passado, sem uma projeção de futuro, desenvolve uma atitude conformista em relação aos mecanismos de dominação que atuam à sua volta. Prisioneiras do presente, as trajetórias juvenis podem tornar-se indeterminadas e erráticas, ao abdicarem do conjunto de responsabilidades e papéis sociais que caracterizam a vida adulta. A construção do futuro passa a ser irrelevante quando a meta é viver um dia de cada vez, numa circularidade hedonista que prolonga indefinidamente o estatuto de jovem (Calvo 2011). As consequências desse modo de articular o tempo estão disseminadas em todos os estratos da sociedade, mas se refletem de forma dramática entre os jovens mais pobres das margens da cidade, dadas as lógicas perversas que atuam no seu território: segregação, estigma, violência, tráfico de drogas.

Na Maré, o mundo do crime está muito próximo dos seus habitantes, espectadores involuntários das demonstrações do seu poder. Este é assente numa "sociabilidade violenta", responsável pela corrosão das solidarie- 
dades locais e pela degeneração de símbolos e valores comuns devido ao recurso à força e à racionalidade instrumental (Machado da Silva 2008:21). Todos os b-boys com os quais conversei tinham amigos ou conhecidos em organizações criminosas, cuja autoridade é reafirmada não apenas pelo uso (ou ameaça) da violência, mas também pela via simbólica. Apoiadas numa cultura de masculinidade exacerbada, essas organizações fazem da honra individual, da coragem e da exibição de bens materiais distintivos (motos, tênis, roupas, armas) evidências do seu estatuto superior (Zaluar 2004). Os bailes funk da Maré são os eventos de destaque para festejar este domínio, quando bandidos desfilam com pesados cordões de ouro no pescoço e armas em punho, numa clara afirmação de poder. Integradas por uma pequena minoria da população, essas redes criminosas controlam o espaço público da Maré, impondo um conjunto de regras e coações que os moradores são obrigados a acatar, sob pena de sofrerem pesadas represálias. De uma maneira mais ou menos ritualizada, a violência representa a fórmula privilegiada de os traficantes regularem os vínculos sociais no bairro, mantendo uma determinada ordem e hierarquia. ${ }^{34}$

As particularidades de uma vivência tão próxima da economia clandestina do tráfico de drogas fazem com que os espaços relacionais dos jovens da Maré sejam marcados pelo contraste. De um lado, um antigo companheiro de infância faz a "contenção" (segurança) da favela com um fuzil nas mãos, de outro, colegas frequentam cursos de pré-vestibular com o objetivo de ingressar no ensino superior. Desnaturalizar as violências a que são expostos cotidianamente e saber reconhecer as qualidades do bairro não são desafios fáceis.

Tanta coisa ruim que é vista como algo normal, e tem coisas boas que passam desapercebidas, que fica difícil para um jovem dentro da Maré diferenciar o que é bom do que é ruim. Porque moleque cresce vendo "malucos" com arma na mão, isso é a coisa mais normal do mundo. Ao mesmo tempo ele vê um cara cheio de livros na bolsa, estudando para caramba. Tem esse contraste. É como eu falei no começo, se não tiver apoio da família, pode acabar "dando mole". Conheço gente que está nessa vida de tráfico, por quê? Também por falta de opção, às vezes. Tem gente que fala: "Porque fulano é safado, se quisesse não entraria". Depende muito. Ninguém pode julgar uma pessoa assim. Eu conheço muita gente [do tráfico] que falo com respeito: "E aí fulano, beleza?!". "Qual foi Rômulo, beleza?!". Continuo falando com eles, mas dou uma afastada [Rômulo, 17 anos. Entrevista, 5 de novembro de 2009].

Para aqueles que sentem a angústia do desemprego ou do baixo salário, em que as perspectivas de consumo, ascensão e reconhecimento social são diminutas, a promessa de dinheiro fácil acenada pelo tráfico de drogas pode 
ser tentadora. Quando se está encurralado entre duas ordens diversas - de um lado, o tráfico e, do outro, as instituições do Estado - enveredar pela carreira do crime não é uma alternativa remota, mas o ingresso numa rede geograficamente próxima. Neste contexto, o hip-hop pode significar um distanciamento desta economia predatória ao propor referências morais e éticas radicalmente opostas. Nas várias conversas, os jovens realçaram o breaking como um estilo que promove a disciplina, a união, a responsabilidade, o respeito e o sentido de coletividade, atributos orientadores das suas sociabilidades, experiências e de seus pontos de vista. Deste modo, podemos considerar que o break dance funciona como uma "escola de moralidade" para os seus adeptos, servindo de "vetor de uma desbanalização da vida cotidiana" capaz de ampará-los contra as influências destrutivas do tráfico de drogas (Wacquant 2002:32).

Todavia, essa "cultura" não pode ser entendida como solução para os problemas de uma violência juvenil que é expressão de dilemas estruturais mais amplos da sociedade brasileira, tais como a extrema desigualdade social, a inconsistência das políticas públicas do Estado, a precariedade laboral e a criminalização da pobreza e do consumo de drogas. A adesão ao estilo não serve de "magia" para neutralizar essas forças objetivas, pois há antigos dançarinos do bairro que entraram nas quadrilhas do tráfico. Este é o caso de Alisson, um dos b-boys com quem tinha maior contato e estima na Maré. Ele ingressou na quadrilha que atuava na sua vizinhança em 2012, sendo preso e condenado a dez anos prisão por tráfico de drogas. A complexidade desta questão também foi abordada pelo b-boy Welton. "O breaking 'salva'?", perguntei.

Não salva não, cara. Se bem que o breaking salva muitos, mas outros não. Porque o hip-hop é uma rota de fuga, basta a pessoa querer entrar. Se escolher entrar nessa rota, tudo bem, mas se não escolher entrar... Tem três pessoas que entraram na dança comigo em 2002 (que estão vivas) e que hoje são traficantes, bandidos. [...] A gente foge de uma realidade que não queremos, mas é uma realidade que está sempre perto, sempre na nossa frente, mesmo a gente fugindo. Mas a gente vai sempre continuar fugindo dela. Porque aqui é muito fácil encontrar qualquer coisa: boas e ruins. E o hip-hop é uma forma da gente estar desviando a nossa mente daquilo, os nossos pensamentos das coisas ruins [Weltom, 18 anos. Entrevista, 26 de novembro de 2010].

Num bairro marcado pela precariedade das instituições oficiais e dominado por grupos ilegais fortemente armados, o hip-hop serve de contraponto a um estilo de vida violento e alienante. A filiação ao estilo de vida b-boy ajuda os seus adeptos a agirem coletivamente em busca de alternativas que 
permitam ultrapassar as barreiras que os impedem de viver plenamente a juventude, constituindo-se num recurso para desfrutar os prazeres da sua idade e construir um modelo próprio de ser jovem. Participando em coletivos de dança, articulam sentimentos de pertença (ao bairro e ao grupo) que servem de "abrigo virtual" num meio marcado por situações adversas (Agier 2001:8). Desta forma, os dançarinos da Maré criam sociabilidades alternativas - orientadas por atributos de natureza estética e normas ideológicas - que são uma mais-valia para romper a segregação e reclamar os direitos de cidadania. Mais do que uma postura dissidente ou de contestação, a adesão ao estilo b-boy entre os jovens da Maré promove estratégias que reivindicam reconhecimento e aceitação na sociedade dominante. A busca por respeito e dignidade é determinante nas suas vidas, concretizando-se, parcialmente, através da dança.

\section{Considerações finais}

A reflexão sobre a cidade a partir das suas margens para abordar dinâmicas de precarização da vida urbana, estilos de vida e práticas artísticas inovadoras teve como ponto de partida os ensaios de break dance da Maré. A observação alargou-se, depois, aos trajetos e redes sociais dos dançarinos, articulando lugares, imaginários e experiências numa "cidade em processo" (Agier 2011:38). Em face da impossibilidade de obter uma visão holística da cidade (e de suas margens), a busca pela cidade vivida entre os jovens tornou-se uma aposta metodológica, traduzida naquilo que Michel Agier intitula como a "cidade bis" (:32): uma cidade que parte do olhar e das vivências dos citadinos, em que o próprio pesquisador observa situacionalmente e em primeira pessoa. Mais que um pano de fundo, a cidade é uma variável decisiva na construção do conhecimento antropológico, influenciando a observação e os caminhos percorridos durante a pesquisa. De fato, sem conhecer os mecanismos de segregação, criminalização e precarização que atuam no espaço urbano do Rio de Janeiro não seria possível uma aproximação com os jogos de poder, campos de tensão e mapas de significação dos jovens da Maré.

As sociabilidades emergentes criadas pelos b-boys, mas também por rockeiros, emos, grafiteiros, skatistas e rappers do bairro, não podem ser descuradas do Rio de Janeiro enquanto "cidade global". Ora, as razões do hip-hop (e de outras práticas juvenis), adquirir um caráter transnacional e transformar-se no "veículo de uma experiência imaginada" para milhões de jovens em todo o mundo (Fradique 2003:22) estão intimamente relacio- 
nadas com a crescente urbanização e importância das cidades em escala planetária. São elas que conferem uma certa consciência da heterogeneidade de estilos de vida e aceleram a interconexão global, quando expressões musicais, estéticas e identitárias rompem fronteiras nacionais para aprofundar processos de hibridização..$^{35}$ Também as margens das cidades globalizaram-se ao aprofundarem a comunicação entre si, aproveitando-se da relativa democratização do acesso aos meios digitais. Trocas materiais e simbólicas são postas em prática por jovens que habitam regiões marcadas por dinâmicas de segregação e políticas de banimento em distintos pontos do globo, possibilitando, por vezes, a elaboração de projetos artísticos e/ou políticos capazes de lançar todos na direção de um lugar comum.

A etnografia é um exercício indispensável no acompanhamento dos processos culturais, relacionais e políticos que ocorrem nesses espaços "outros", abrindo janelas de observação onde é possível apreender as práticas e as visões de mundo dos pesquisados. Isto não significa reproduzir acriticamente os seus pontos de vista, mas transformar essa experiência de alteridade num conhecimento novo (Magnani 2009). Esta também é a opinião de Michel Agier, para quem as lógicas de "fazer cidade" (2011:41), observadas etnograficamente a partir das experiências concretas dos citadinos e de sua movimentação pela urbe, expressam a sua proposta de antropologia da cidade.

Transpor as barreiras do bairro e as margens da cidade adquiriu um caráter transformador na vida dos dançarinos da Maré, pois permitiu um maior acesso às múltiplas "redes de significado" presentes na metrópole (Geertz 2008). A capacidade de articularem estratégias de trânsito e visibilidade em diferentes mundos sociais faz deles verdadeiros go-betweens (Velho 2001:22), isto é, mediadores que encurtam a distância social e simbólica entre a cidade e as suas margens. Embora a maior parte dos nossos interlocutores não consiga ganhar a vida através da dança, muitos deles aprofundaram relações com ONGs do bairro, aproveitando melhor as oportunidades que estavam à sua disposição: ingressaram em cursos profissionalizantes, tornaram-se professores de break dance e organizaram eventos de hip-hop. Aprenderam, assim, a negociar com representantes do Estado e do chamado terceiro setor, articulando o estatuto b-boy e a trajetória de vida num bairro marginalizado para dar legitimidade às suas produções artísticas. A ampliação da experiência urbana é um recurso valioso e se reflete em maiores oportunidades de obtenção de empregos com carteira assinada e na possibilidade de conhecer pessoas de estratos sociais diferenciados, quando são exigidas competências próprias, sejam elas intelectuais, linguísticas ou de etiqueta. ${ }^{36}$ 
Ser b-boy (e pertencer à cultura hip-hop) configura também uma posição de força capaz de reposicioná-los de forma a não ficarem presos às categorias estigmatizantes. Passaram a exercer uma "cidadania insurgente" (Holston 2013) que propõe novos usos da cidade, desenvolvendo ações mobilizadoras que disputam o significado de ser pobre, negro e morador de favela. Ao transformarem a Maré num dos expoentes do circuito de break dance do Rio de Janeiro, invertem as lógicas culturais que privilegiam as áreas nobres da cidade, pondo em causa a tradicional dicotomia centro-periferia. Por outro lado, a convergência em termos estéticos, morais e territoriais entre os dançarinos ajuda-os a construir identidades positivas, satisfazendo o desejo dos jovens de serem alguém numa sociedade que os quer condenar à subalternidade.

O break dance é prática de lazer e divertimento, mas também um treino lúdico para os desafios da vida adulta, incutindo nos jovens da Maré a motivação necessária para pôr em prática audazes projetos de futuro. Transformado num "farol de virtude" a resguardá-los das dificuldades da vida, o break dance desloca os muros invisíveis fabricados pela segregação, pelo preconceito e pelo tráfico de drogas, estimulando uma experiência de alteridade ampliadora dos direitos dos jovens à cidade.

Recebido em 29 de julho de 2016

Aprovado em 20 de dezembro de 2016

Otávio Ribeiro Raposo é pós-doutorando em antropologia pelo Centro de Investigação e Estudos de Sociologia (CIES-IUL), Lisboa, Portugal.

E-mail: <otavio_raposo@iscte.pt> 


\section{Notas}

1 Este artigo resulta da pesquisa de doutorado em Antropologia, financiada pela Fundação para a Ciência e a Tecnologia (FCT) e desenvolvida no quadro institucional do Instituto Universitário de Lisboa (ISCTE-IUL) e do Centro de Investigação e Estudos de Sociologia (CIES-IUL), em Portugal, em parceria com o Programa de Pós-Graduação de Sociologia e Antropologia (PPGSA) da Universidade Federal do Rio de Janeiro (IFCS-UFRJ).

2 Break dance ou breaking é o principal estilo de dança do hip-hop, em que os movimentos variam do acrobático e esportivo até a estilização de movimentos da capoeira, artes marciais e ginástica olímpica. O hip-hop é um movimento cultural urbano formado por quatro vertentes artísticas: rap, dj, grafite e break dance.

3 Regressei várias vezes ao bairro nos anos posteriores para acompanhar as transformações ocorridas na Maré e no seio do grupo.

4 Realizei entrevistas semidirigidas com 15 jovens do grupo de dançarinos da Maré e 17 pessoas entre antigos moradores, membros e dirigentes de ONGs, professores de break dance e representantes locais das favelas, desenvolvendo o método biográfico entre os primeiros.

5 O Instituto Brasileiro de Geografia e Estatística (IBGE) estimou que, em 2010, viviam 129.770 habitantes na Maré. No entanto, um censo organizado pela Redes de Desenvolvimento da Maré (2014) e outras organizações do bairro contabilizou cerca de 140 mil residentes.

6 Segundo a pesquisa "Os muros do invisível", realizada pelo Observatório de Favelas, Action Aid e Núcleo de Estudos e Pesquisas sobre Favelas e Espaços Populares, 73\% da população da Maré acreditam que o muro tem como finalidade ocultar a favela. Para mais informação consultar: http://www.jb.com.br/rio/noticias/2011/09/30/moradores-da-mare-acham-que-muro-foi-construido-para-esconder-favela-diz-pesquisa/

7 O bloco carnavalesco da Maré, "Se Benze que Dá", realizou um vídeo a denunciar a construção do muro que pode ser visualizado em: http://www.youtube. com/watch?v=HX5tyiTD2vg

8 Insuficientemente alto e feito de material transparente, o muro não obstrui completamente a visão do bairro. Contudo, o impacto visual que a Maré causava para quem visitava o Rio de Janeiro pela primeira vez foi "saneado".

9 As profundas intervenções urbanas que o Rio de Janeiro está a atravessar visam muito mais o lucro das empresas privadas do que o benefício da sociedade como um todo. Remoções em massa de moradores das favelas entraram novamente na pauta das políticas públicas, sem que haja um diálogo satisfatório com a população afetada. Para mais informações consultar o Dossiê do Comitê Popular Rio da Copa e Olimpíadas (2013). 
10 A presença de favelas nos bairros nobres de São Paulo não é tão comum. A área de moradia dos habitantes mais pobres está concentrada fora das zonas centrais e valorizadas da cidade, num padrão de segregação que fez das suas periferias o principal local de alteridade, diferente do Rio de Janeiro. Para um maior aprofundamento sobre o padrão de segregação em São Paulo consultar Caldeira (2000).

11 A população mais que duplicou (120\%) em apenas 20 anos no Rio de Janeiro, passando a ter 520 mil habitantes em 1890, enquanto o crescimento do número de domicílios ficou em 74\% (Silva \& Barbosa 2005:25).

12 Esta proximidade física costuma ser acompanhada de fortes distâncias sociais, pois, como explicou Roberto DaMatta, cada um sabe exatamente o seu lugar no hierarquizado espaço social brasileiro (1997:171).

13 Sem querer aprofundar as limitações do uso deste conceito por Robert Park (1973), uma vez que se sobressaem as ideias de seleção e ordem natural (ou desordem) na configuração dessas "regiões morais", importa reconhecer o mérito do autor na busca de sentido sobre as classificações socioespaciais correntes, uma tentativa inovadora de pensar modelos intermédios entre o indivíduo isolado e a cidade holisticamente inapreensível.

$14 \mathrm{O}$ invulgar modelo de cidadania brasileiro estaria ligado às particularidades da sua colonização e ao desenvolvimento de um Estado-nação com forte influência cultural ibérica e da religião católica, fatores que, na opinião de DaMatta (1997), impediram a eclosão de uma revolução individualista.

15 Foi nesse período que ocorreu a primeira grande campanha contra a favela. $\mathrm{O}$ seu principal dinamizador, o médico e jornalista Augusto de Mattos Pimenta, definia a favela como um problema de saúde pública que devia ser combatido, considerando-a como "lepra da esthetica" (Valladares 2008).

16 Esta noção foi problematizada também por Robert Park (1973), para quem os comportamentos anômicos teriam origem em certas "regiões morais" da cidade, incentivados pelo "contágio social".

17 Verificou-se um exponencial aumento do número de vítimas de homicídio no Brasil que, em 2010, foi de 49.932 indivíduos, um aumento de $259 \%$ em comparação com 1980 quando foram mortas 13.910 pessoas. A taxa de homicídio para 100 mil habitantes disparou de 11,7 para 26,2, um crescimento que resultou em mais de 1 milhão de assassinatos nas últimas três décadas (Waiselfisz 2011).

18 O ex-governador do Rio de Janeiro, Sérgio Cabral Filho, defendeu, em 2007, a legalização do aborto como meio de reduzir a violência, considerando que as altas taxas de natalidade das favelas as transformavam numa "fábrica de produzir marginal". Entrevista disponível em: http://g1.globo.com/Noticias/Politica/0 „MUL1557105601,00-CABRAL+DEFENDE+ABORTO+ CONTRA+VIOLENCIA+NO+RIO+D E+JANEIRO.html

19 As quadrilhas do tráfico de drogas são formadas, sobretudo, por rapazes negros e mestiços com menos de 30 anos de idade, tornando esses indivíduos mais propensos a serem humilhados pela polícia ou alvo de desconfianças pelas facções criminosas. 
20 Phil Cohen (1972) foi um dos fundadores desta linha de pensamento ao defender que a cultura juvenil divergente expressaria uma forma de contestação aos valores sistêmicos.

21 Milícia é um grupo paramilitar composto por policiais, bombeiros e militares que também exerce um controle violento e territorial.

22 A figura 2 foi feita por mim a partir das informações recolhidas durante a pesquisa.

23 O Conjunto Marcílio Dias não aparece no mapa em virtude do seu afastamento em relação ao núcleo original da Maré, estando a cerca de $3 \mathrm{~km}$ da praia de Ramos.

24 São raros os moradores que utilizam equipamentos culturais localizados em favelas então dominadas por quadrilhas rivais à sua área de residência. O Piscinão de Ramos é uma das poucas exceções. Equipamentos que se encontram em áreas de fronteira, como é o caso da Lona Cultural Herbert Vianna, são subutilizados devido ao medo dos moradores de serem surpreendidos por um tiroteio.

25 O street dance tem muitas semelhanças com o break dance, privilegiando os movimentos enérgicos, sincronizados e coletivos.

26 As crews são grupamentos informais de jovens que se reveem em práticas comuns, neste caso o break dance.

27 Alguns dos dançarinos das favelas Vila do Pinheiro e Vila do João não queriam se expor ao risco de entrar em áreas dominadas por quadrilhas rivais às da sua área de residência, treinando num espaço cedido pela associação de moradores.

28 Tracei os percursos de sete dançarinos da Maré a partir de mapas do bairro, onde também assinalei os locais de lazer e de sociabilidade que passaram a frequentar após a adesão ao break dance. Além de expressar modos de circular e orientar-se na Maré, esses mapas foram muito úteis para perceber o modo como os jovens lidam com as fronteiras impostas pelas quadrilhas de tráfico de drogas. Um agradecimento especial à Rita Gorgulho pelo apoio técnico na elaboração dos mapas.

29 Esta área era controlada pela facção ADA até maio de 2009. A partir desta data teve início uma violenta disputa entre duas quadrilhas rivais (TCP e ADA), que culminou na expulsão desta última. Durante os quase seis meses de duração do conflito morreram mais de 40 pessoas, segundo informações de moradores e ONGs, naquela que foi uma das épocas mais sangrentas da Maré. Para mais informações consultar Raposo (2014).

30 A fronteira à direita no mapa deixou de existir quando os territórios por ela delimitados foram incorporados pelo TCP após meses de intensos confrontos. As outras duas fronteiras mantêm-se e demarcam os limites das quadrilhas: TCP CV e Milícia (da direita para esquerda).

31 Neurose é um termo "nativo" dos habitantes das favelas cariocas, sobretudo da sua juventude, para caracterizar um estado emocional de medo e paranoia decorrente da violência entre as quadrilhas armadas que atuam no seu território. 
32 O evento de break dance mais concorrido entre os dançarinos da Maré chama-se Master Crew, uma das competições brasileiras mais importantes. Frequentadores desde 2009, acompanhei-os nas edições de 2010, quando competiram nas batalhas entre crews, e 2015, quando foram até lá para encontrar amigos e curtir o evento.

$33 \mathrm{O}$ "conhecimento" é apontado como o $5^{\circ}$ elemento do hip-hop, acrescentado por Afrika Bambaataa, um dos fundadores deste movimento cultural.

34 Esta situação não se alterou quando a Maré passou a ser ocupada por tropas do Exército e da Marinha, a partir de março 2014, com o objetivo de instalar Unidades de Polícia Pacificadora (UPP). A influência das facções criminosas manteve-se nesse período, apesar da venda de drogas ter deixado de ocorrer de forma ostensiva, da menor presença de jovens armados e da proibição dos bailes funk. Após a saída das forças militares, 15 meses depois, a inauguração das UPP no conjunto de favelas do bairro não se concretizou, e o controle social repressivo sobre os moradores voltou a se reger, exclusivamente, pela "metáfora da guerra" (Leite 2015:384).

35 A ampliação da circulação de símbolos e manifestações artístico-culturais em circuitos transnacionais não implica a homogeneização cultural, tampouco a perda dos sentidos locais, considerando-se que as mesmas são constantemente (re) construídas e legitimadas através de práticas cotidianas localizadas geograficamente.

36 A fragilidade desse capital simbólico pode ter consequências graves, como explicou Philippe Bourgois na sua análise sobre os descendentes de porto-riquenhos do Harlem, para os quais o "choque cultural" e o isolamento no bairro tinham por efeito torná-los inaptos a conseguir empregos na área de serviços (2010:162). Contrariamente aos interlocutores deste autor, os dançarinos da Maré podem ser considerados "biculturais" (:188), pois conseguem manipular com primor diferentes códigos de conduta: do "jogo de cintura" que se requer numa favela dominada pela economia clandestina das drogas às formalidades burocráticas exigidas para desenvolverem projetos artísticos. 


\section{Referências bibliográficas}

ABRAMO, Helena Wendel. 1997. "Considerações sobre a tematização da juventude no Brasil". Revista Brasileira de Educação, 5/6:25-35.

ADERALDO, Guilhermo \& RAPOSO, Otávio. 2016. "Deslocando fronteiras: notas sobre intervenções estéticas, economia cultural e mobilidade juvenil em áreas periféricas de São Paulo e Lisboa". Horizontes Antropológicos, 22(45):279-305.

AGIER, Michel. 2001. "Distúrbios identitários em tempos de globalização". Mana. Estudos de Antropologia Social, 7(2):7-33.

. 2011. Antropologia da cidade: lugares, situações, movimentos. São Paulo: Editora Terceiro Nome. . 2015. "Do refúgio nasce o gueto: antropologia urbana e política dos espaços precários". In: Patrícia Birman; Márcia Leite; Carly Machado \& Sandra Carneiro (orgs.), Dispositivos urbanos e trama dos viventes: ordens e resistências. Rio de Janeiro: Editora FGV. pp. 33-53.

BOURDIEU, Pierre. 2008 [1984]. Cuestiones de sociología. Madrid: Ediciones Istmo.

BOURGOIS, Philippe. 2010. En busca de respeto. Vendiendo crack en Harlen. Buenos Aires: Siglo Veintiuno Editores.

CALDEIRA, Teresa Pires do Rio. 2000. Cidade de muros: crime, segregação e cidadania em São Paulo. São Paulo: Editora 34/ Edusp.

CALVO, Enrique. 2011. "A roda da fortuna: viagem à temporalidade juvenil". In: José Machado Pais, René Bendit \& Vítor Ferreira (orgs.), Jovens e rumos. Lisboa: Imprensa de Ciências Sociais. pp. 39-57.
CANCLINI, Nestor Garcia; CRUCES, Francisco \& POZO, Maritza (orgs.). 2012. Jóvenes, culturas urbanas y redes digitales. Barcelona: Ariel.

COHEN, Phil. 1972. "Sub-cultural conflict and working class community". Working Papers in Cultural Studies, $\mathrm{n}^{\circ}$ 2, CCCS. Birmingham: University of Birmingham. Mimeo.

COMITÊ POPULAR RIO DA COPA E DAS OLIMPÍADAS. 2012. Megaeventos e violações dos direitos humanos no Rio de Janeiro. Dossiê do Comitê Popular da Copa e Olimpíadas do Rio de Janeiro. Disponível em: http://comitepopulario.wordpress. com/ 2012/04/20/baixe-agora-dossie-megaeventos-e-violacoes-dos-direitos-humanos-no-rio-de-janeiro/ Acesso em 24/11/2012.

CORDEIRO, Graça Índias. 2010. "As cidades fazem-se por dentro. Desafios de etnografia urbana". Cidades, Comunidades e Territórios, 20/21:111121.

DAMATTA, Roberto. 1997. Carnavais, malandros e heróis: para uma sociologia do dilema brasileiro. Rio de Janeiro: Editora Rocco.

DAS, Veena \& POOLE, Deborah (eds.). 2004. Anthropology in the margins of the State. Oxford: School of American Research Press/ James Currency.

DE TOMMASI, Lívia. 2013. "Culturas de periferia: entre o mercado, os dispositivos de gestão e o agir político". Revista Política \& Sociedade, 12:11-34. . 2014. "Tubarões e peixinhos: histórias de jovens protagonistas". Revista Educação e Pesquisa, 40(2):533-547.

DURKHEIM, Émile. 1968. Les formes élementaires de la vie religieuse. Paris: PUF. 
EAMES, Edwin \& GOODE, Judith Granich. 1977. Anthropological of the city. An introduction to urban anthropology. Englewood Cliffs, New Jersey: Prentice Hall.

FERRÁNDIZ, Francisco. 2002. “Espíritus de la violencia. Los malandros em el culto de María Lionza". In: Carles Feixa \& Francisco Ferrándiz (orgs.), Violencia y culturas. Barcelona: FAAEE. pp. 2-30.

FOUCAULT, Michel. 1977. Vigiar e punir: nascimento da prisão. Petrópolis: Editora Vozes.

FRADIQUE, Teresa. 2003. Fixar o movimento. Representações da música rap em Portugal. Lisboa: Publicações Dom Quixote.

FRIDMAN, Luis Carlos. 2008. "Morte e vida favelada". In: Machado da Silva (org.), Vida sob cerco: violência e rotina nas favelas do Rio de Janeiro. Rio de Janeiro: Editora Nova Fronteira. pp. 77-98.

GEERTZ, Clifford. 2008. A interpretação das culturas. Rio de Janeiro: LTC Editora.

GIROUX, Henry. 1996. Fufitive cultures: race, violence \& youth. London: Routledge.

HOLSTON, James. 2013. Cidadania insurgente: disjunções da democracia e da modernidade no Brasil. São Paulo: Companhia das Letras.

JEGANATHAN, Pradeep. 2004. "Checkpoint: anthropology, identity and the State". In: Veena Das \& Deborah Poole (org.), Anthropology in the margins of the state. Oxford: School of American Research Press/ James Currency. pp. 67-80.

LEFEBVRE, Henri. 2012. O direito à cidade. Lisboa: Estúdio e Livraria Letra Livre.
LEITE, Márcia Pereira. 2015. "De territórios da pobreza a territórios de negócios: dispositivos de gestão das favelas cariocas em contexto de "pacificação'". In: Patrícia Birman; Márcia Leite; Carly Machado \& Sandra Carneiro (orgs.), Dispositivos urbanos e trama dos viventes: ordens e resistências. Rio de Janeiro: Editora FGV. pp. 377-401. . \& MACHADO DA SILVA, Luiz Antonio. 2013. "Circulação e fronteiras no Rio de Janeiro: a experiência urbana de jovens moradores de favelas em contexto de 'pacificação'". In: Neiva Vieira da Cunha \& Gabriel de Santis Feltran (orgs.), Sobre periferias. Novos conflitos no Brasil contemporâneo. Rio de Janeiro: Lamparina Editora/ Faperj. pp. 146-158.

LOPES, João Teixeira. 2000. A cidade e a cultura: um estudo sobre práticas culturais urbanas. Porto: Afrontamento.

MACHADO DA SILVA, Luiz Antonio. 2006. "Favela, crime violento e política no Rio de Janeiro". In: Fernanda Lopes de Carvalho (org.), Observatório da cidadania 2006. Arquitetura da exclusão. Rio de Janeiro: IteM/Ibase. pp. 76-81.

. (org.). 2008. Vida sob cerco: violência e rotina nas favelas do Rio de Janeiro. Rio de Janeiro: Editora Nova Fronteira.

. \& LEITE, Márcia. 2008. "Violência, crime e polícia: o que os favelados dizem quando falam desses temas". In: Luiz Antonio Machado da Silva (org.), Vida sob cerco: violência e rotina nas favelas do Rio de Janeiro. Rio de Janeiro: Editora Nova Fronteira. pp. 47-76.

MAGNANI, José Guilherme. 2009. "Etnografia urbana". In: Carlos Fortuna \& Rogerio Proença Leite (orgs.), Plural de cidade: novos léxicos urbanos. Coimbra: Edições Almedina. pp.101-113. 
PARK, Robert. 1973. "A cidade: sugestões para a investigação do comportamento humano no meio urbano". In: Otávio Velho (org.), O fenômeno urbano. Rio de Janeiro: Zahar Editores. pp. 26-67.

PAIS, José Machado. 1994. "A geração yô-yô". Atas do III Congresso Luso-Afro-Brasileiro de Ciências Sociais - Dinâmicas multiculturais. Novas faces, outros lugares. Lisboa: Instituto de Ciências Sociais da Universidade de Lisboa. pp. 111-125.

RAPOSO, Otávio. 2014. "'This is Iraq. People are afraid.' Resistance and mobilization in the Maré favelas (Rio de Janeiro)". Vibrant, 11(1):11-49.

REDES - Redes de Desenvolvimento da Maré. 2014. Censo de Empreendimentos Maré. Rio de Janeiro: Redes da Maré \& Observatório de Favelas.

SILVA, Jailson \& BARBOSA, Jorge Luiz. 2005. Favela: alegria e dor na cidade. Rio de Janeiro: Senac Rio Editora.

VALLADARES, Licia do Prado. 2008. A invenção da favela: do mito de origem a favela.com. Rio de Janeiro: FGV Editora.

VELHO, Gilberto. 2001. "Biografia, trajetória e mediação". In: Gilberto Velho \& Karina Kuschnir (orgs.), Mediação, cultura e política. Rio de Janeiro: Aeroplano Editora. pp. 13-28.
2002. A utopia urbana: um estudo de antropologia social. Rio de Janeiro: Jorge Zahar Editor. . 2004. Individualismo e cultura: notas para uma antropologia $d a$ sociedade contemporânea. Rio de Janeiro: Jorge Zahar Editor. . \& ALVITO, Marcos (orgs.). 1996. Cidadania e violência. Rio de Janeiro: UFRJ/FGV.

WACQUANT, Loic. 2002. Corpo e alma: notas etnográficas de um aprendiz de boxe. Rio de Janeiro: Relume Dumará Editora.

WAISELFISZ, Julio Jabob. 2011. Mapa da violência 2012: os novos padrões da violência homicida no Brasil. São Paulo: Instituto Sangari.

ZALUAR, Alba. 1996. "A globalização do crime e os limites da explicação local". In: Gilberto Velho \& Marcos Alvito (orgs.), Cidadania e violência. Rio de Janeiro: Editora UFRJ/ Editora FGV. pp. 48-68. . 2004. "Violência, cultura e poder". In: Fátima Regina Cecchetto (org.), Violência e estilos de masculinidade. Rio de Janeiro: FGV Editora. pp. 7-33. . \& ALVITO, Marcos (orgs.). 2006. Um século de favela. Rio de Janeiro: FGV Editora.

\section{Sites citados}

http://www.jb.com.br/rio/noticias/2011/09/30/moradores-da-mare-acham-que-muro-foi-construido-para-esconder-favela-diz-pesquisa/. Acesso em 03/05/2012.

http://www.youtube.com/watch?v=HX5tyiTD2vg. Acesso em 04/05/2010.

http://g1.globo.com/Noticias/Politica/0,"MUL155710-5601,00-CABRAL+DEFENDE +ABORTO+CONTRA+VIOLENCIA+NO+RIO+DE+JANEIRO.html. Acesso em 24/09/2009. 


\section{CARTOGRAFIA DA DANÇA. SEGREGAÇÃO E ESTILOS DE VIDA NAS MARGENS DA CIDADE}

\author{
CARTOGRAFÍA DEL BAILE. \\ SEGREGACIÓN Y ESTILOS DE VIDA \\ EN LOS MÁRGENES DE LA CIUDAD
}

\section{Resumo}

Este artigo examina o modo inovador como um grupo de dançarinos de break dance das favelas da Maré (Rio de Janeiro) tem conseguido romper com as dinâmicas de segregação, num território onde os confrontos armados entre as facções do tráfico de drogas e a ação truculenta da polícia impõem fortes constrangimentos à livre circulação dos moradores. Com base numa pesquisa etnográfica, exponho como os jovens se apropriam da cultura hip-hop para ampliar a experiência urbana e contestar os dispositivos de confinamento que os querem manter isolados e anônimos nas margens da cidade. Ao se tornarem dançarinos reconhecidos dentro e fora da Maré, utilizam o componente performativo como meio de ascender a uma existência valorizada, criando identidades positivas que subvertem o seu lugar na hierarquia social.

Palavras-chave: Segregação, Juventude, Favela, Hip-hop, Cartografia.

\section{Resumen}

Este artículo examina la manera innovadora en la que un grupo de bailarines de break dance de las favelas de la Maré (Río de Janeiro) ha logrado romper con las dinámicas de segregación, en un territorio donde las confrontaciones armadas entre las facciones de tráfico de drogas y la acción truculenta de la policía imponen fuertes restricciones a la libre circulación de los habitantes. Basándose en una investigación etnográfica, en el presente trabajo se expone cómo los jóvenes se apropian de la cultura hip-hop para ampliar la experiencia urbana y contestar los dispositivos de confinamiento que los quieren mantener aislados y anónimos en los márgenes de la ciudad. Al convertirse en bailarines reconocidos dentro y fuera de la Maré, utilizan el elemento performático como forma de ascender a una existencia valorada, creando así identidades positivas que subvierten su lugar en la jerarquía social.

Palabras clave: Segregación, Juventud, Favela, Hip-hop, Cartografía. 
CARTOGRAPHY OF THE DANCE. SEGREGATION AND LIFESTYLE AT THE MARGINS OF THE CITY

\begin{abstract}
This article examines how a group of break-dancers in Maré, a favela (shanty town) in Rio de Janeiro, has succeeded in severing the dynamics of segregation in a territory where armed conflicts between drug trafficking gangs and the aggressive behaviour by the police impose heavy constraints on the free movement of its residents.
\end{abstract}

Based on ethnographic research, I describe how these young people employ hip-hop culture to expand the urban experience and contest the mechanisms of confinement that are intended to keep them isolated and anonymous in urban outskirts. By becoming renowned dancers in and out of the Maré, they use performance as a means to ascend to a valued existence, creating positive identities that subvert their place in the social hierarchy.

Key words Segregation, Youth, Shanty town, Hip-hop, Cartography. 
